\title{
Electrodeposición de vanadio y níquel de los asfaltenos de crudos pesados
}

\section{CHEMICAL ENGINEERING \\ $\mathrm{V}$ and Ni electrochemical deposition from asphaltenes in heavy oils}

\author{
Natalia Afanasjeva $\S^{*}$, William H. Lizcano -Valbuena**, Nayeli Aristizabal, Ivone Mañozca \\ *DepartamentodeQuímica, Universidad delValle, Cali, Colombia \\ §natalia.afanasjeva@correounivalle.edu.covilliam.lizcano@correounivalle.edu.conay3_21@hotmail.com, \\ ivonne2212@hotmail.com
}

\section{Resumen}

La presencia de metales en los asfaltenos, especialmente del vanadio y níquel, puede ser una fuente de productos de valor agregado, pero representan una desventaja en las refinerías ya que no solo contaminan los productos sino que envenenan los catalizadores durante el proceso de craqueo catalítico. El objetivo de este proyecto fue el montaje de una celda electroquímica (donde se utilizó una barra de grafito como electrodo de trabajo, un alambre de Pt como contraelectrodo y un electrodo de $\mathrm{Ag} / \mathrm{AgNO}{ }_{3}$ como electrodo de referencia) para la caracterización y electrodeposición de $\mathrm{V}$ y Ni contenidos en los extractos resino-asfaltenicos y asfaltenos purificados de los crudos pesados. Los análisis de alta resolución antes y después de la deposición fueron: análisis elemental, FT-IR y absorción atómica. El efecto de las variables electroquímicas como potencial de trabajo, tiempo de reacción y material del electrodo en el proceso de electroreducción se evaluó por voltametría cíclica (VC) y cronoamperometría en dos medios: (I) Tetrahidrofurano y $\mathrm{LiClO}_{4}$ al $0.02 \mathrm{M}$, (II) $20 \% \mathrm{de}_{3} \mathrm{OH}_{3} 0.5 \% \mathrm{de}_{3} \mathrm{PO}, 0.1 \mathrm{M}$ de $\mathrm{LiClO}_{4}$ en acetonitrilo. Los resultados obtenidos se discuten comparándolos con los obtenidos por el método tradicional de desmetalización en ambientes de digestión ácida.

Palabras clave: Asfaltenos, celda electroquímica, crudos pesados, metales $\mathrm{V}$ y Ni, voltametría cíclica.

\begin{abstract}
Heavy metals are present in porphyrins in oil asphaltenes. High content of $\mathrm{V}$ and $\mathrm{Ni}$ could be attractive to produce high value metal oxides. These metals are undesirable due to corrosion issues and catalyst contamination in cracking processes. The purpose of this project was to prepare an electrochemical cell, with graphite work electrode, wire $\mathrm{Ag}$ counterelectrode and a $\mathrm{Ag} / \mathrm{AgNO}_{3}$ reference electrode, in order to evaluate and make the electrochemical characterization and deposition of $\mathrm{V}$ and $\mathrm{Ni}$ content in resin asphaltene concentrate and pure asphaltenes obtained from Colombian heavy oils. High resolution analytics before and after the deposition was done: elemental analysis, FT-IR, and atomic absorption.

The variables as work potential, reaction time and electrode materials during the electro-reduction was evaluated by cyclic voltammetry and chronoamperommeter in two solutions: (I) Tetrahydrofuran and $\mathrm{LiClO}$ at $0.02 \mathrm{M}$, and (II)

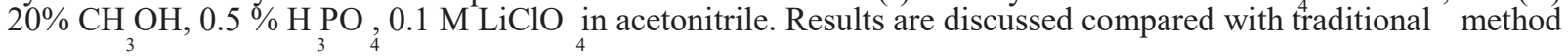
of demetallization by acid digestion.
\end{abstract}

Keywords: Asphaltenes, clectrochemical cell, cyclicvoltametrics , heavy oils, $V$ and Ni metals. 


\section{Introduction}

Light Oil reserves are depleting and needs for transportation fuel liquids poses new problems to Refineries in order to meet the growing demand. Research and development in heavy oils has dramatically raised in last years (Campetrol, 2009) specially focus on resin-asphaltene concentrates (CRA). In Colombia $40 \%$ of the proven reserves corresponds to heavy oils, present in 6 of 16 basins. For example one of these basins Llanos Orientales, counts on $6,806 \mathrm{MMbbl}$ to 319,455 MMbbl probable reserves and actually participate with $73.5 \%$ of the total oil production (Colombia y energía, 2013). Refining the heavy oils in the near future will help to solve production of fuel liquids for transportation.

Nature and structure of both resins and asphaltenes strongly depend on the origin of the oil (Nomura et al., 2005). Heavy oil from same reservoirs can show different properties (Tharanivasan, 2012). ASTM D6560-12, ASTM D3279 and ASTM D4124 are the most used methods for separation and characterization of asphaltenes and resins. Usually research laboratories use the precipitation of these components with aliphatic solvents and extraction with toluene in a Soxhlet reflux system, allowing a good separation of resins from asphaltenes (Aske, 2002). Citations on different models of the asphaltene structure are found, being one of them a model that considers a pillared layers of aromatic structures array (Leyva et al., 2013).

Resins and asphaltenes content in a concentrate type CRA generate industrial and environmental issues because they are highly viscous, high sulfur content, and contains more than 28 metals in form of traces of $\mathrm{Pb}, \mathrm{V}, \mathrm{Ni}, \mathrm{Cr}, \mathrm{TI}, \mathrm{Fe}$ and $\mathrm{Al}$ (Welter et al., 2009), being nickel and vanadium in the porphyrin forms the most important in the heavy cuts. Metal concentration depends on origin of oil. Some authors reports vanadium content $1.0 \times 10^{-7}$ $\mathrm{Kg} / \mathrm{L}$ to $1.2 \times 10^{-3} \mathrm{Kg} / \mathrm{L}$, and for Ni $1.5 \times 10^{-4} \mathrm{Kg} / \mathrm{L}$ (Ali \& Abbas, 2006); Colombian Castilla oil was reported having metal content in asphaltenes 1,686 and $431 \mu \mathrm{g} / \mathrm{g}$ for $\mathrm{V} \mathrm{y} \mathrm{Ni}$, (Mogollón, 1997).
Demetallization by electrolysis is a new route that might be used at moderated conditions of temperature in an convenient mix of solvents in a electrolytic solution. An efficiency of $85 \%$ is reported in a process of demetallization (Duyck et al., 2006) giving an opportunity to add value extracting the metals present in a heavy oil.

Vanadium and nickel that deactivate hydrocracking catalyst are present in two forms: heterocyclic porphyrins reported by Treibs A. (1936), and in non - porphyrin form with undefined structure (Khuhawaretetal., 2012). Porphyrinsareclassified as: etioporphyirines (Etio-), deoxofiloeritroetioporphyrin (DPED) observed by Barwise y Roberts (Fish \& Wines, 1984) and later cited by Baker and Louda (1988), who discovered tetrahydrobenzoporphyrins, benzo-(rhodo)-etio-, and benzo-(rhodo)porphyrin. Ni in heavy oil is present in form of etioporphyrins (etio III) and are less investigated due to its low concentration compared with Vanadium that is present in form of vanadyl ion $\left(-\mathrm{VO}^{2+}\right)$, axe coordinated to an oxygen and four Nitrogen atoms in structures type vanadyl-deoxofiloeritroetioporphyrin (VODPEP) and in vanadylbenzotioporphyrins (VOB) (Yin et al., 2006) as showed in Figure 1.

Commercial demetallization processes are at high pressures (1500-2500 psi) and temperature (380$450{ }^{\circ} \mathrm{C}$ ), as demetallization process (Mello et al., 2012) in presence of Hydrogen that reacts with organometallics in the organic matrix (including metallporphyrins). Al laboratory level the most common method for determination of $\mathrm{V}$ and $\mathrm{Ni}$ is the acid digestion with strong organic acids at high temperature generating corrosive vapors.

Clean alternatives of demetallization are electrochemical processes as the one proposed by Welter et al. (2009), porphyrines present in asphaltenes, according to this work, ease the demetallization because they are electroactive and redox reactions occur under mild conditions of pressure and temperature. It was reported that metal elimination from a Venezuelan heavy crude oil Ayacucho resulted in a $84 \%$ extraction of Vanadium (IV ) meso-tetra-phenolporphyrin and 
$78 \%$ V ( IV ) octa-etioporphyrin ( VOHDM-OEP) using commercial porphyrins by electrochemical techniques. With oil porphyrins extractions rates were $66.4 \%$ and $64.1 \%$ using graphite electrode during 90 minutes and Pt electrode for 120 minutes. ( Campero \& Espinosa, 1996). The factors that affect this method: electrolytic solution, electrode material, time of reaction and reduction potential.
In this research the electrodeposition was carried out in two solutions evaluating the effect of electrochemical variables by voltammetric determination in the extraction of $\mathrm{V}$ and $\mathrm{Ni}$ from Castilla heavy crude oil on different electrode materials.

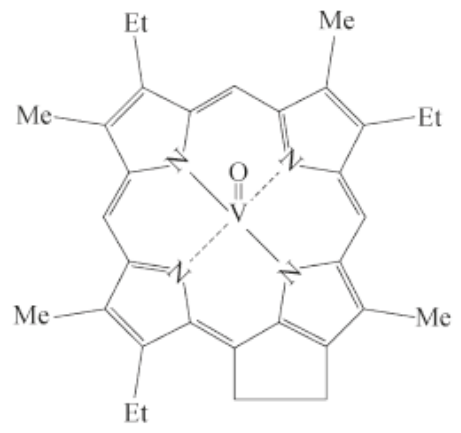

a.

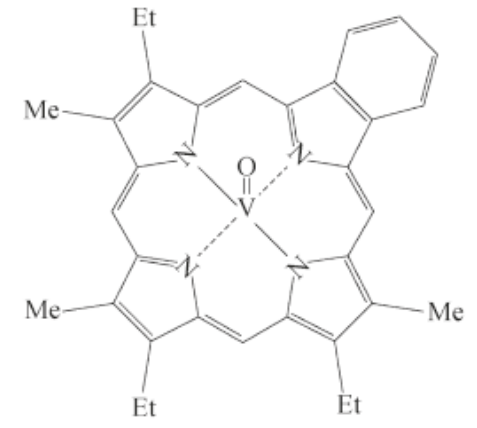

b.

Figure 1. Chemical structure of (a) vanadyl deoxophylloerythroetioporphyrin (VODPEP) and (b) vanadyl benzoetioporphyrin (VOB). (Taken from Fish \& Wines, 1984).

\section{Methodology}

\subsection{Characterization of CRA and asphaltene probes.}

CRA and asphaltenes probes obtained from Castilla crude oil were precipitated with nheptane and characterized by means of AE, FTIR techniques and atomic absorption (AAS).

\subsubsection{Elemental analysis}

Content of carbon, hydrogen, sulfur and nitrogen was determined using $2 \mathrm{mg}$ grinded probe in a FLASHEA 1112 series Analizator, Thermo ELECTRON CORPORATION at a temperature of $1000^{\circ} \mathrm{C}$.

\subsubsection{Infrared Spectroscopy with Fourier Transform (FT-IR).}

A spectrometer SHIMADZU IR-Affinity 1 was used for this analysis. It was determined the presence of functional groups and vibration bands assigned to asphaltenes, and also the anion $\mathrm{V}=$ $\mathrm{O}$ band at $1030 \mathrm{~cm}^{-1}$, that is clear signal of the presence of metals in asphaltenes.

\subsubsection{Quantification of $\mathrm{V}$ and $\mathrm{Ni}$ in Castilla} CRA and asphaltenes. Acid wet digestion for metal extraction.

Probes of CRA and asphaltenes weight $3.0 \pm$ $0.0001 \mathrm{~g}$ were calcined at a temperature $525{ }^{\circ} \mathrm{C}$ during 6 hours to eliminate organic material. Digestion procedure is a modification of ASTM D5863 Standard. Digestion was carried out taking an acid mix $\mathrm{HNO}_{3} / \mathrm{HCl}(2: 5)$. Tubes were sealed and a digest plate type HACH DRB 200 was used. Conditions of wet acid digestion were: temperature $=100{ }^{\circ} \mathrm{C}$ for 2 hours followed by hot filtration and weighed with distilled water. Quantification of metals was done in a Spectrometer Perkin Elmer 100, at working conditions shown in Table 1. 
Table 1. Conditions for metal analysis by flame atomic absorption of Castilla crude oil.

\begin{tabular}{|c|c|c|c|c|}
\hline Element & $\begin{array}{c}\text { Current } \\
(\mathrm{mA})\end{array}$ & Slit & $\lambda(\mathrm{nm})$ & $\begin{array}{c}\text { Relation } \\
\text { fuel/oxidant }\end{array}$ \\
\hline Vanadium (V) & 40 & 0,7 & 318,4 & $\begin{array}{c}\text { Acetylene/ } \\
\text { Nitrous } \\
\text { oxide }\end{array}$ \\
\hline Nickel (Ni) & 15 & 0,2 & 232,0 & $\begin{array}{c}\text { Acetylene } \\
\text { Air } \\
\end{array}$ \\
\hline
\end{tabular}

\subsection{Electrochemical cell}

An electrochemical cell was designed for experiments previous to electrolysis. A second cell with three compartments as seen in figure 2 with a volume probe capacity of $250 \mathrm{ml}$ and a heating jacket with thermostat was built. Working electrode was a graphite bar with a $\mathrm{O}$ content 5.1 $\%$ and $\mathrm{Cl} 0.37 \%$ (measured by dispersive $\mathrm{X}$-ray spectroscopy, EDX). A SEM analysis was also taken as shown in figure 3. Conterelectrode was built with a Pt wire $0.25 \mathrm{~mm}$ thickness. A silver wire $2 \mathrm{~cm}$ length immersed in a $0.01 \mathrm{M} \mathrm{LiCO}_{4}$ and $0.01 \mathrm{M} \mathrm{AgNO}_{3}$ in $\mathrm{CH}_{3} \mathrm{CN}$ solution was used as reference.

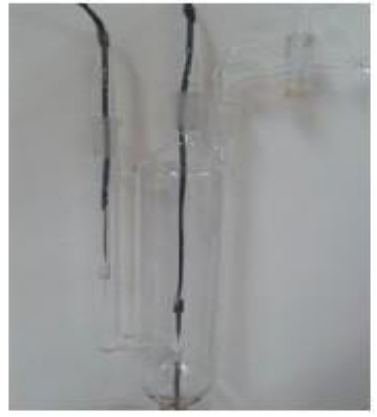

a)

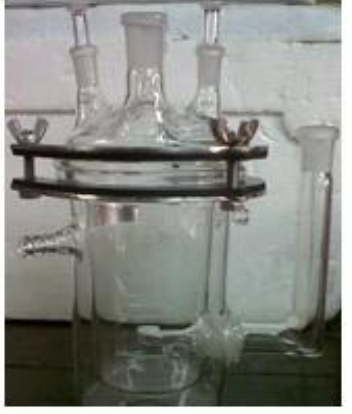

b)
Figure 2. Electrochemical cell a) two compartments and $b$ ) three compartments.

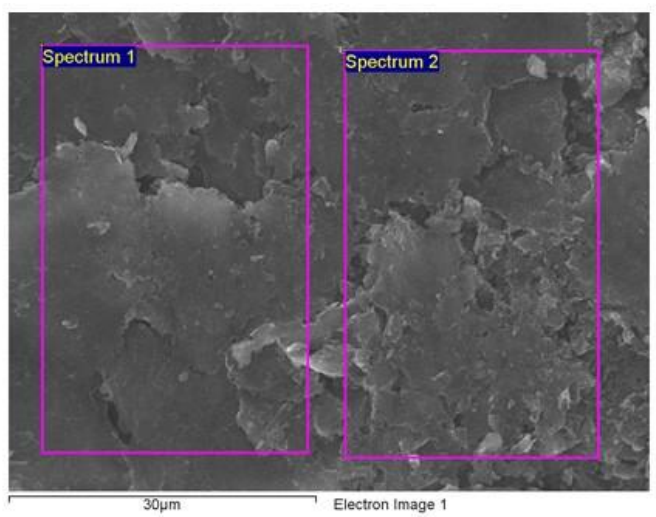

Figure 3. SEM of the graphite bar used as working electrode

\subsection{Extraction of $\mathrm{V}$ and $\mathrm{Ni}$ by electrodeposition}

Experiments on a potentiostat Autolab M101 were done to evaluate the effect of electrochemical variables (potential screen, reaction time and electrode materials for the electrodeposition) in the two mentioned electrolytic solution by voltamperommetry.

\subsection{Cyclic voltammetry electrolytic solution and Castilla crude oil.}

Experiments were done at different scanning velocities from 0 to $-2000 \mathrm{mV}$ vs. $\mathrm{Ag} / \mathrm{Ag}^{+}$. $5 \mathrm{~g}$ of each product were used for $\mathrm{V}$ and $\mathrm{Ni}$ electrodeposition. A solution with $90 \mathrm{ml} \mathrm{Li} \mathrm{Cl} \mathrm{O}_{4}$, $0.2 \mathrm{M}$ in THF in presence of a protonating agent (mix $70 \mathrm{ml}$ THF and $20 \mathrm{ml} \mathrm{CH}_{3} \mathrm{OH}$ ) was used. Electrodeposition was carried at conditions that were previously determined. All the experiments were at room temperature and the time of the reaction was 24 hours under agitation.

\subsection{Chronoamperommetry of Castilla crude oil}

To obtain the chronoamperommetry for Castilla crude oil $5 \mathrm{~g}$ were added to a solution with $150 \mathrm{ml}$ $\mathrm{LiClO}_{4} \quad 0.2 \mathrm{M} \mathrm{THF}$ in solution in the presence of the protonating agent $\mathrm{CH}_{3} \mathrm{OH}$. Measurements were done with permanent agitation at a constant potential either -1.0 or $-1.7 \mathrm{~V}$. Purge was done every time with Nitrogen during $10 \mathrm{~min}$.

\section{Results}

Concentrate content (CRA) in Castilla crude oil was determined as $23.21 \%$.Also resin content $2.81 \%$ and $20.04 \pm 1.1 \%$ asphaltenes were found, that is according with the classification of this crude oil as heavy oil having an API gravity of 9.6, showing a high resin and asphaltene content.

From the element analysis and the $\mathrm{H} / \mathrm{C}$ relation, empirical formula and average weight empirical formula (PFEA) were calculated for asphaltenes and CRA concentrate. Empirical formula were $\mathrm{C}_{59} \mathrm{H}_{63} \mathrm{NSO}$ and $\mathrm{C}_{63} \mathrm{H}_{74} \mathrm{NSO}$ for Castilla asphaltenes and CRA respectively. A less content 
of $\mathrm{C}$ and $\mathrm{H}$ in asphaltenes is found due to the resin elimination. The higher relation $\mathrm{H} / \mathrm{C}$ determines a less aromatic character in asphaltenes as shown in Table 2.

Table 2. Data on elemental analysis, H/C relation, empirical formula and WFEA of asphaltenes and CRA Castilla crude oil

\begin{tabular}{|c|c|c|c|c|c|c|c|c|c|}
\hline \multirow{2}{*}{ Sample } & \multirow{2}{*}{$\begin{array}{l}\text { Mass } \\
(\mathrm{mg})\end{array}$} & \multirow[b]{2}{*}{$\mathbf{N}$} & \multicolumn{3}{|c|}{ Element content $(\%)$} & \multirow[b]{2}{*}{$\mathrm{O}$} & \multirow{2}{*}{ Relation $\mathrm{H} / \mathrm{C}$} & \multirow{2}{*}{$\begin{array}{l}\text { Empirical } \\
\text { formula }\end{array}$} & \multirow{2}{*}{$\begin{array}{c}\text { WFEA (g/ } \\
\text { mol) }\end{array}$} \\
\hline & & & $\mathrm{H}$ & $\mathrm{C}$ & $S$ & & & & \\
\hline CRA & 2.76 & 1.54 & 8.15 & 84.03 & 4.01 & 2.25 & 1.16 & $\mathrm{C}_{63} \mathrm{H}_{74} \mathrm{NSO}$ & 892 \\
\hline Asphaltenes & 2.45 & 1.65 & 7.48 & 83.66 & 4.22 & 2.98 & 1.07 & $\mathrm{C}_{59} \mathrm{H}_{63} \mathrm{NSO}$ & 833 \\
\hline
\end{tabular}

FT-IR spectra for CRA and asphaltenes from Castilla (see figures 4 and 5) showed similarity at the bands in same frequencies. Each one gives absorption bands for aromatic structures at 3010 and $3235\left(v_{\mathrm{CH}-\mathrm{Ar}}\right), 1599$ and $1615\left(\mathrm{v}_{\mathrm{C}=\mathrm{O}}\right.$ aromatic), 861 and $864\left(\gamma_{\mathrm{CH}-\mathrm{Arl}}\right)$ or ring structures with $\mathrm{H}$ alone, $810-808\left(\gamma_{\mathrm{CH}-\mathrm{Ar} 23}\right)$ or ring with $2 \mathrm{H}$ nearby, 726 and $746 \mathrm{~cm}^{-1}\left(\gamma_{\mathrm{CH}-\mathrm{Ar} 4}^{\mathrm{CH}-\mathrm{Ar} 2,3}\right)$ or rings with $4 \mathrm{H}$ nearby and vibration bands assigned to aliphatic groups in 2922-2921 $\left(\mathrm{v}_{\mathrm{CH} 3+\mathrm{CH} 2}\right)$ and 1375,1455 $\mathrm{cm}^{-1}\left(\delta_{\mathrm{CH} 3+\mathrm{CH} 2}\right)$. Ether signal appears only for asphaltenes at $1029 \mathrm{~cm}^{-1}$ and carbonyl signal at $1637 \mathrm{~cm}^{-1}$ only for CRA. Both probes give bands associated to a N-H bond.

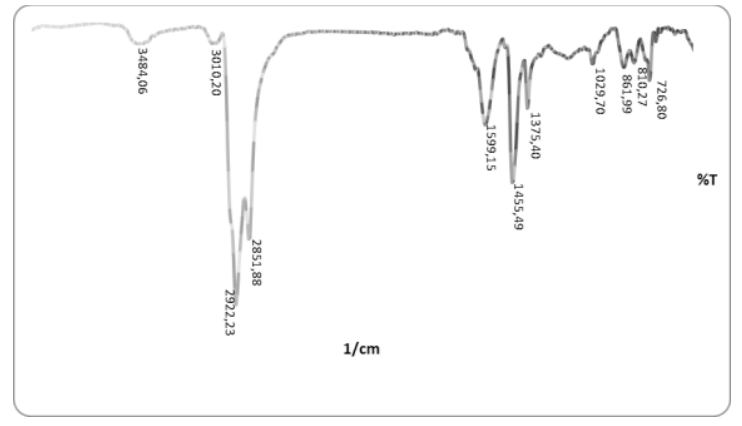

Figure 4. FT-IR of Castilla crudeoil asphaltenes

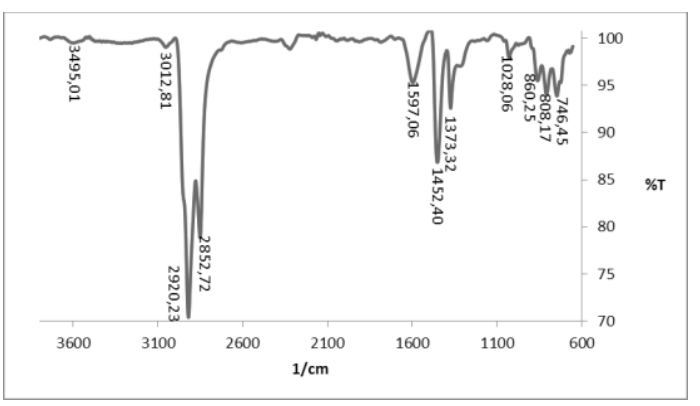

Figure 5. FT-IR of Castilla crude oil CRA

\subsection{Results of content quantification for $V$ and $\mathrm{Ni}$ in CRA and Asphaltenes by flame atomic absorption}

Results for calibration curves for determining $\mathrm{V}$ and Ni content (absorbance \pm 0.001 ) versus concentration is shown in figure 6 . Using equation (1) that relates absorbance and metal concentration a content of $4.41 \times 10^{-4} \mathrm{Kg} / \mathrm{L}$ of $\mathrm{V}$ and $5.86 \times 10^{-5} \mathrm{Kg} / \mathrm{L}$ of Ni were found in Castilla crude oil probes. Similar results are reported by the Colombian Oil Institute (ICP): V y Ni content in Castilla crude oil are $1.85 \times 10^{-3} \mathrm{Kg} / \mathrm{L}$ y $3.82 \times 10^{-}$ ${ }^{4} \mathrm{Kg} / \mathrm{L}$ respectively ( Campetrol, 2009).
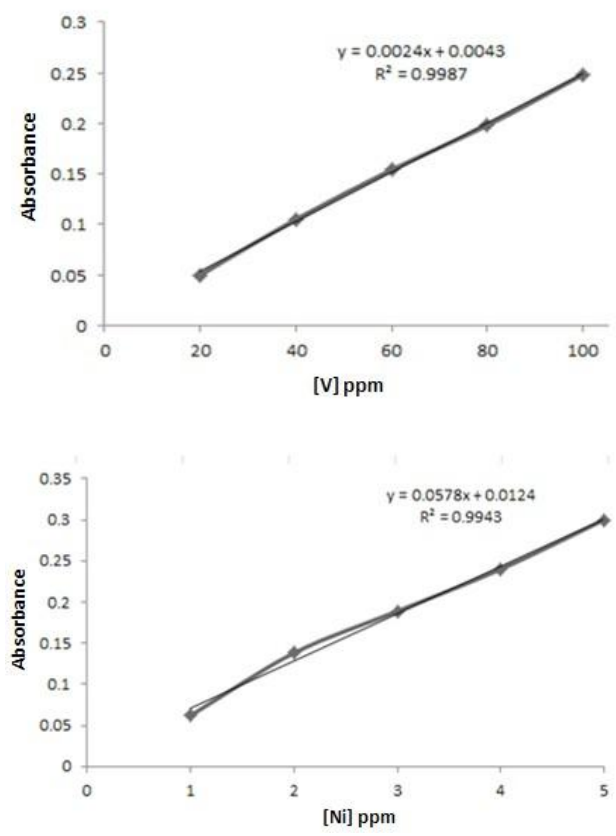

Figure 6. Calibration curves for Castilla crude oil: a) vanadium and b) nickel. 


$$
[y]=m[x]+b
$$

Where:

concentration $=[\mathrm{x}]=[\mathrm{Kg} / \mathrm{L}]$, absorbance $=[\mathrm{y}]=$ [dimensionless $]$, tangent $=[\mathrm{m}]=[\mathrm{L} / \mathrm{Kg}]$,

intercept $=[\mathrm{b}]=[$ dimensionless $]$

\subsection{Cyclic voltammetry (VC) electrolytic medium and Castilla crude oil.}

Effect of electrolytic medium on the metal recuperation by electrochemical way by means of VC was studied. In the figure 7 voltamperogramms at 0 and $2,300 \mathrm{mV}$ vs $\mathrm{Ag} /$ $\mathrm{AgCl}$, are shown. Electrolytic medium on Pt does not show associated peaks with reactions on the catalyst in the interval of potential measurements. However, at more negative potential an increase in current densities it is observed, a fact that could be assigned to a medium decomposition as reported in a publication (Márquez et al., 2006).

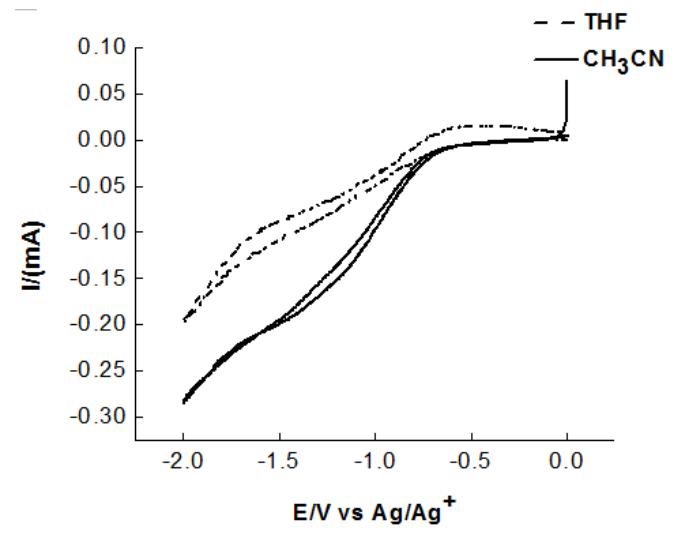

Figure 7. Voltamperogramelectrolytic medium THF and $\mathrm{CH}_{3} \mathrm{CN}$ on Ptelectrode at $100 \mathrm{mV} / \mathrm{s}$.

On the graphite electrode surface as working electrode (figure 8), no peaks were observed in the voltamperommetric experiments. That indicates that the chosen potential interval is the adequate.

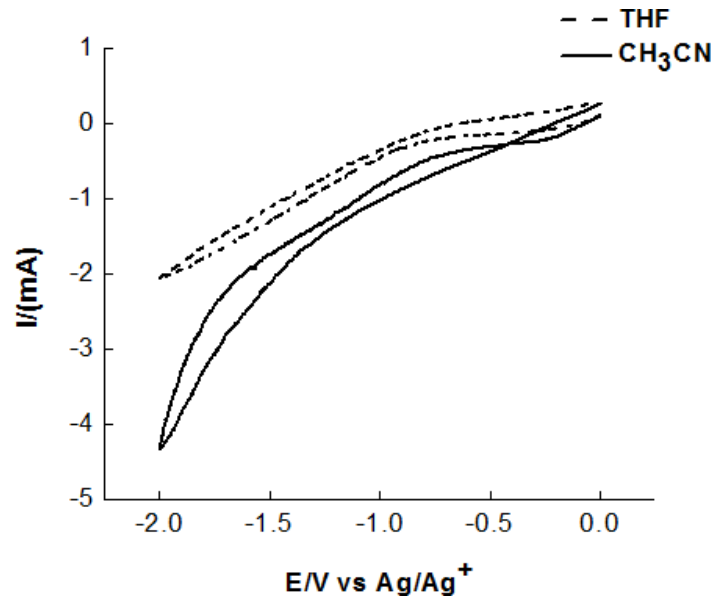

Figure 8. Voltamperogram electrolytic medium THF and $\mathrm{CH}_{3} \mathrm{CN}$ on graphite electrode at $100 \mathrm{mV} / \mathrm{s}$.

In figure $9 \mathrm{a}$ is shown the voltamperogramm of Castilla crude oil in acetonitrile, observing a reduction wave nearby to $-1.0 \mathrm{~V}$ that could be assigned to the anion radical formation caused by the reduction of the $\pi$ system in the porphyrinic ring. In figure $9 \mathrm{~b}$ peak of the radical anion formation appears at $-1.2 \mathrm{~V}$, displaced 0.2 $\mathrm{V}$ to less negatives potentials due probably to a solvent effect. In this case the effect of THF on the solubility of the petroporphyrins in the solvent (Yin C., 2008).

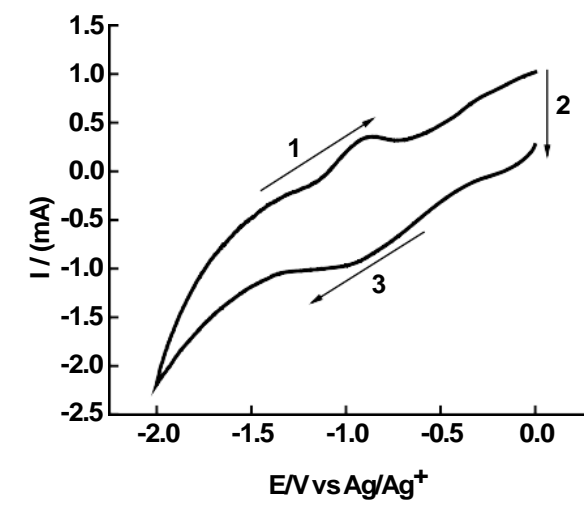




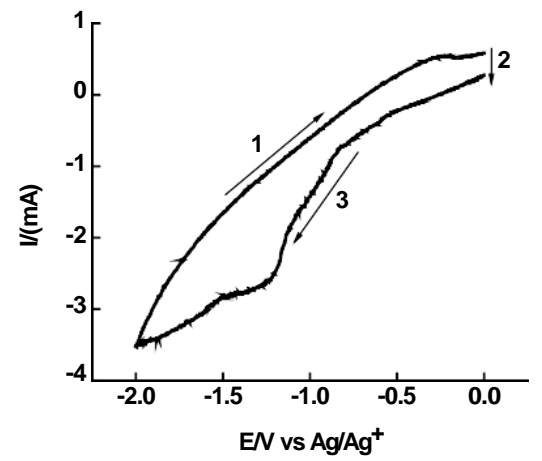

$b$.

Figure 9. Voltamperogram electrolytic medium: a) $0.5 \%$ $\mathrm{HClO}_{4} / 20 \% \mathrm{CH}_{3} \mathrm{OH} / / 0.1 \mathrm{M} \mathrm{LiClO} / \mathrm{CH}_{3} \mathrm{CN}$ (b) electrolytic medium $0.02 \mathrm{M} \mathrm{LiClO}_{4} / 20 \% \mathrm{CH}_{3} \mathrm{OH} / / \mathrm{THF}$ of Castilla crude oil. Scan speed $100 \mathrm{mv} / \mathrm{s}$.

With the purpose to find the reaction time the probe stayed in contact with the working electrode for 15 hours, finding that the peak at $-1.0 \mathrm{~V}$ (figure 10a) is less remarkable that the same peak but with the electrode at a contact time of 2 hours (figure 10b
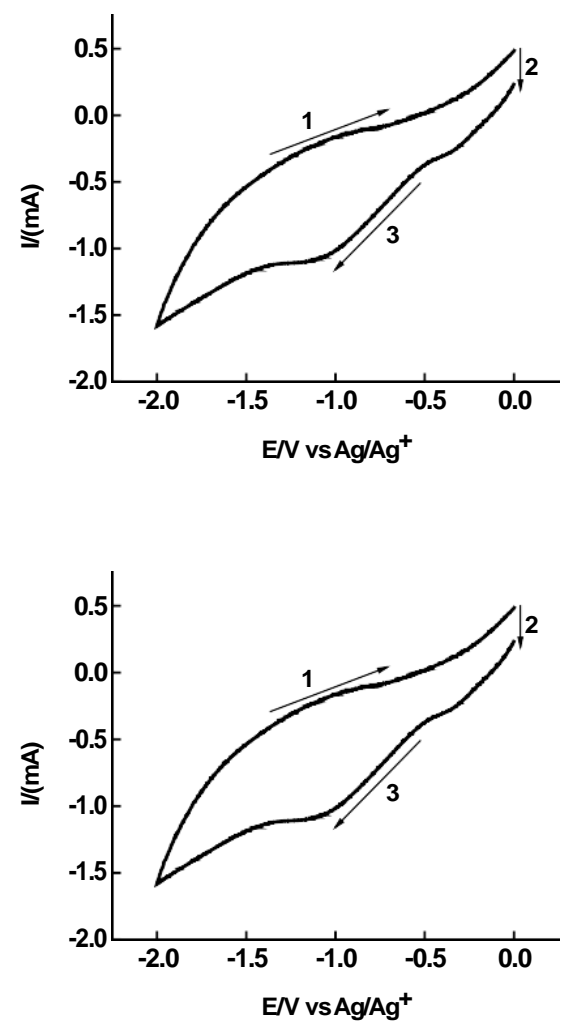

Figure 10. Voltamperogram electrolytic medium $0.02 \mathrm{M}$ $\mathrm{LiClO}_{4} / 20 \% \mathrm{CH}_{3} \mathrm{OH} / / \mathrm{THF}$ of Castilla crude oil after (a) 2 hours and (b) 15 hours. Scan speed $100 \mathrm{mv} / \mathrm{s}$.
The conclusion could be that the reaction occurs very slow and other electrochemical parameters must be studied in a more detailed way to diminish time reaction or find a right crude oil concentration to increase the product yield.

\subsection{Chronoamperommetry Castilla crude oil}

Chronoamperommetry Castilla crude is shown in figure 11. It can be observed a typical current characteristic, that it means than the species on the electrode surface are slowly diminishing with time. It is remarkable that under constant and mild agitation concentration on electrode active surface can reach a stationary value current. Respecting to $\mathrm{V}$ and $\mathrm{Ni}$ concentrations the molar relation $\mathrm{mM}$ of $\mathrm{V}: \mathrm{Ni}$ was calculated and resulted in a value of 8:1. With this molar relation and the $\mathrm{C}$ charge obtained from the chronoamperommetry of Castilla crude the $\mathrm{V}$ and $\mathrm{Ni}$ mass deposited was calculated as $2,37 \times 10^{-5} \mathrm{~g}$.

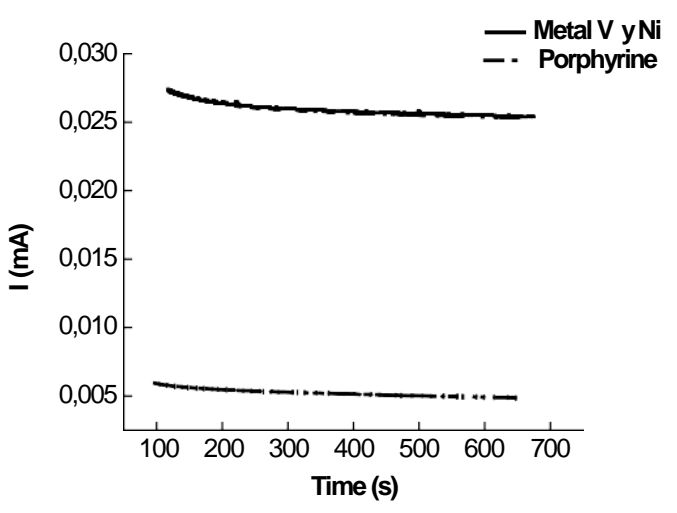

Figure 11. Chronoamperometry electrolytic medium $0.02 \mathrm{M}$ $\mathrm{LiClO}_{4} / 20 \% \mathrm{CH}_{3} \mathrm{OH} / /$ THFofCastillacrudeoil

\section{Conclusions}

Concentration of $\mathrm{V}$ and $\mathrm{Ni}$ metals determined by atomic absorption in this work was greater in an order of magnitude than the concentrations reported by Colombian Oil Institute for the same probes of Castilla crude oil. $\left(4.4 \times 10^{-4} \mathrm{Kg} / \mathrm{L}\right.$ for $\mathrm{V}$ and $5.86 \times 10^{-5} \mathrm{Kg} / \mathrm{L}$ for $\mathrm{Ni}$ ). With the experimental data obtained by cyclic voltammetry a potential threshold of 0 to $-2,3000 \mathrm{~V}$ was determined. In this interval the medium does not present reduction peaks or collateral reactions that could affect 
Castilla crude oil probe. Besides, it was possible to find the reaction time for the probe in contact with working electrode as 15 hours, finding the peak at $-1.0 \mathrm{~V}$. It was chosen the best graphite material with less impurities for the elaboration of the working electrode referred to SEM technique. Electrodeposition reaction is slow and is affected by electrochemical factors as reaction time and the yield of the process. The low deposition of the metals $\mathrm{V}$ and $\mathrm{Ni}$ by this electrochemical technique is probably due to the quantity of other metals present in crude oil that interfere, because they form different structures of organic and non organic compounds like $\mathrm{Cl}$ and $\mathrm{S}$ salts that are known to be in crude oil. Porphyrins containing $\mathrm{V}, \mathrm{Ni}$ and $\mathrm{Fe}$ (III) or Fe (II) are very stable due to the high chelating properties and difficult to go through a reduction process.

\section{Acknowledgement}

Authors want to thank Vicerrectoría de investigaciones Universidad del Valle, for the financial support to the Project CI- 7902 "Determination of $\mathrm{V}$ and $\mathrm{Ni}$ of petroporphyrins by por electrodeposition". Also to the Chemist José Márquez who helped in the cell design.

\section{References}

Ali, M.F., \& Abbas, S. (2006). A review of methods for the demetallization of residual fuel oils. Fuel Process. Technol., 87 (7), 573-584

Aske, N. (2002). Characterisation of Crude Oil Components, Asphaltene Aggregation and Emulsion Stability by Means of Near Infrared Spectroscopy and Multivariate Analysis. Doctoral Thesis, Department of Chemical Engineering. Norwegian University of Science and Technology, Trondheim, Norwegian.

ASTM International.Annual Book of Standards ASTM D5863 (2011). Method A: Determination of nickel, vanadium, $\mathrm{Fe}$ and $\mathrm{Na}$ in crude oils and residual fuels by flame atomic absorption spectroscopy. USA. West Conshohocken, PA.
Campero, B. A., \& Espinosa, M. (1996). Distribution of vanadylporphyrins in a Mexican off shore heavy crude oil. Fuel Process. Technol., 46 (3), 171-182

Campetrol (Cámara Colombiana de servicios petroleros).(2009). La producción de los distintos tipos de crudo en Colombia. Bogotá .Colombia

Colombia Energía, la revista de la industria energética colombiana (2013). Crudos pesados un nuevo horizonte. http://www.colombiaenergia. com/ediciones

Duyck, C., Miekeley, N., Porto Da Silveira, C.L., Aucélio, R.Q., Campos, R.C., Grinberg, P., \& Brandao, G.P. (2007). The determination of trace elements in crude oil and its heavy fractions by atomic spectrometry. Spectrochim. Acta. Part B. Spectrosc. 62 (9), 939-951.

Fish, R., Komelenic, \& J., Wines, B. (1984). Characterization and comparison of vanadyl and nickel compounds in heavy crude petroleums and asphaltenes by reverse-phase and size-exclusion liquid chromatography/graphite furnace atomic absorption spectrometry. Anal. Chem. 56 (13), 2452-2460.

Khuhawar, M.; Mirza, M., \& Jahangir, T. (2012). Determination of metal ions in crude oil. Intech., 65, 121-144.

Leyva, C., Ancheyta, J., Berrueco, C., \& Millán, M. (2013). Chemical characterization of asphaltenes from various crude oils. Fuel Process. Technol., 106, 734-738.

Márquez, J., Pérez de Márquez, O., Balladores, Y.(2006). Demetalización de petroporfirinas por vía electroquímica directa. Tesis de doctorado, Departamento de Química, Universidad de los Andes, Mérida, Venezuela.

Mello, P.A., Pereira, J.S., Mesko, M.F., Barin, J.S., \& Flores, E.M. (2012). Sample Preparation Methods for Subsequent Determination of Metals and Non-Metals in Crude Oil. Anal. Chimica Acta, 746, 15-36. 
Mogollon, L., Rodriguez, R., Larrota, W., Ortiz, C., \& Torres, R., (1997). Fraccionamiento y desmetalizacion biocatalitica de asfaltenos de crudo Castilla. CT\&F Ciencia tecnología y futuro 1 (3), 109-121.

Nomura, M., Rahimi, P.M., \& Koseoglu, O.R. (2005). Advances in characterization and utilization of asphaltenes. Am. Chem. Soc. 895, $1-17$.

Tharanivasan, K. A. (2012). Asphaltene Precipitationfrom Crude Oil Blends, Conventional Oils, and Oils with Emulsified Water. Ph.D. thesis . Department of Chemical and Petroleum Engineering. University of Calgary, Alberta, Canada.

Welter, K., Salazar, E., Balladores, Y., Márquez, O. P., Márquez, J., \& Martínez, Y. (2009). Electrochemical removal of metals from crude oil samples. Fuel Process. Technol., 90 (2), 212-221.

in, C., Tan, X., Mu, K., Stryker, J.M., \& Gray, M.R. (2008). Associative $\pi-\pi$ interactions of condensed aromatic compounds with vanadyl or nickel porphyrin complexes are not observed in the organic phase. Energy\& Fuels, 21, 2465-2469.

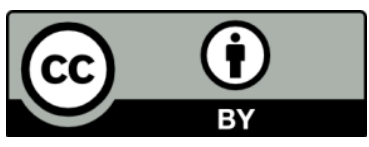

Revista Ingeniería y Competitividad por Universidad del Valle seencuentra bajouna licencia Creative Commons Reconocimiento - Debe reconocer adecuadamente la autoría, proporcionar un enlace a la licencia e indicar si se han realizado cambios. Puede hacerlo de cualquier manera razonable, pero no de una manera que sugiera que tiene el apoyo del licenciador o lo recibe por el uso que hace. 